\title{
Chemical Analysis of the Interface between Hybrid Organic- Inorganic Perovskite and Atomic Layer Deposited $\mathrm{Al}_{2} \mathrm{O}_{3}$
}

Dibyashree Koushik, ${ }^{\dagger} \odot$ Lotte Hazendonk, ${ }^{\dagger}$ Valerio Zardetto, ${ }^{\ddagger}$ Vincent Vandalon, ${ }^{\dagger}$ Marcel A. Verheijen, ${ }^{\dagger, \S}$ Wilhelmus M.M. Kessels, ${ }^{\dagger,}{ }^{\ddagger}$ and Mariadriana Creatore ${ }^{*},+$,

${ }^{\dagger}$ Department of Applied Physics, Eindhoven University of Technology (TU/e), P.O. Box 513, 5600 MB Eindhoven, The Netherlands

${ }^{\ddagger}$ Solliance, High Tech Campus 21, 5656 AE Eindhoven, The Netherlands

${ }^{\S}$ Philips Innovation Labs, High Tech Campus 11, 5656 AE Eindhoven, The Netherlands

\section{Supporting Information}

ABSTRACT: Ultrathin metal oxides prepared by atomic layer deposition (ALD) have gained utmost attention as moisture and thermal stress barrier layers in perovskite solar cells (PSCs). We have recently shown that 10 cycles of $\mathrm{ALD} \mathrm{Al} \mathrm{Al}_{3}$ deposited directly on top of the $\mathrm{CH}_{3} \mathrm{NH}_{3} \mathrm{PbI}_{3-x} \mathrm{Cl}_{x}$ perovskite material, are effective in delivering a superior PSC performance with $18 \%$ efficiency (compared to $15 \%$ of the $\mathrm{Al}_{2} \mathrm{O}_{3}$-free cell) with a long-term humidity-stability of more than 60 days. Motivated by these results, the present contribution focuses on the chemical modification which the $\mathrm{CH}_{3} \mathrm{NH}_{3} \mathrm{PbI}_{3-x} \mathrm{Cl}_{x}$ perovskite undergoes upon growth of $\mathrm{ALD} \mathrm{Al}_{2} \mathrm{O}_{3}$. Specifically,

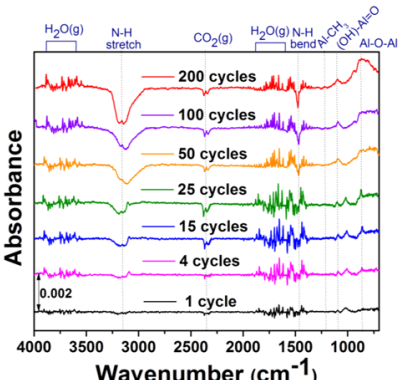
Wavenumber $\left(\mathrm{cm}^{-1}\right)$

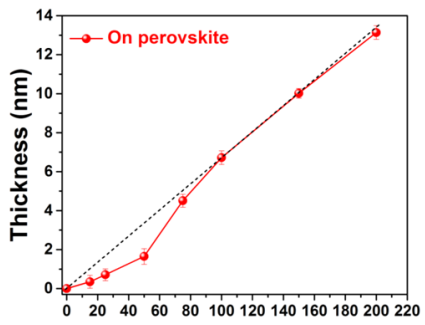

Number of $\mathrm{Al}_{2} \mathrm{O}_{3}$ cycles we combine in situ Infrared (IR) spectroscopy studies during film growth, together with X-ray photoelectron spectroscopy (XPS) analysis of the $\mathrm{ALD} \mathrm{Al}_{2} \mathrm{O}_{3} /$ perovskite interface. The IRactive signature of the $\mathrm{NH}_{3}{ }^{+}$stretching mode of the perovskite undergoes minimal changes upon exposure to ALD cycles, suggesting no diffusion of ALD precursor and co-reactant $\left(\mathrm{Al}\left(\mathrm{CH}_{3}\right)_{3}\right.$ and $\left.\mathrm{H}_{2} \mathrm{O}\right)$ into the bulk of the perovskite. However, by analyzing the difference between the IR spectra associated with the $\mathrm{Al}_{2} \mathrm{O}_{3}$ coated perovskite and the pristine perovskite, respectively, changes occurring at the surface of perovskite are monitored. The abstraction of either $\mathrm{NH}_{3}$ or $\mathrm{CH}_{3} \mathrm{NH}_{2}$ from the perovskite surface is observed as deduced by the development of negative $\mathrm{N}-\mathrm{H}$ bands associated with its stretching and bending modes. The IR investigations are corroborated by XPS study, confirming the abstraction of $\mathrm{CH}_{3} \mathrm{NH}_{2}$ from the perovskite surface, whereas no oxidation of its inorganic framework is observed within the ALD window process investigated in this work. In parallel, the growth of $\mathrm{ALD} \mathrm{Al}_{2} \mathrm{O}_{3}$ on perovskite is witnessed by the appearance of characteristic IR-active $\mathrm{Al}-\mathrm{O}-$ $\mathrm{Al}$ phonon and $(\mathrm{OH})-\mathrm{Al}=\mathrm{O}$ stretching modes. Based on the IR and XPS investigations, a plausible growth mechanism of $\mathrm{ALD} \mathrm{Al}_{2} \mathrm{O}_{3}$ on top of perovskite is presented.

KEYWORDS: perovskite, atomic layer deposition, $\mathrm{Al}_{2} \mathrm{O}_{3}$, infrared spectroscopy, $\mathrm{X}$-ray photoelectron spectroscopy

\section{INTRODUCTION}

Three dimensional hybrid organic-inorganic perovskites with the general chemical formula $\mathrm{ABX}_{3}\left(\mathrm{~A}=\mathrm{CH}_{3} \mathrm{NH}_{3}{ }^{+}, \mathrm{HC}\right.$ $\left.\left(\mathrm{NH}_{2}\right)_{2}^{+}\right), \mathrm{B}=\mathrm{Pb}, \mathrm{Sn}$, and $\mathrm{X}=\mathrm{I}, \mathrm{Cl}, \mathrm{Br}$ ) are characterized by extremely appealing electronic and morphological characteristics which are dominated by the complex interactions interplaying between the organic moiety and the inorganic framework of the lattice. The most conventional perovskite, methylammonium lead iodide $\left(\mathrm{CH}_{3} \mathrm{NH}_{3} \mathrm{PbI}_{3}\right)$ has gained utmost attention in the photovoltaic (PV) community owing to the unprecedented device efficiencies demonstrated in the last eight years. ${ }^{1}$ However, the presence of the volatile $\mathrm{CH}_{3} \mathrm{NH}_{3}{ }^{+}$component in its lattice structure makes this perovskite highly unstable against environmental exposure. ${ }^{2-5}$

Massive efforts have been made to enhance the environmental stability of the perovskite solar cells (PSCs) ${ }^{6}$ by focusing on more stable perovskite compositions ${ }^{7-9}$ and/or adopting the approach of interface engineering. ${ }^{10-16}$ In the latter case, the application of atomic layer deposited (ALD) metal oxides in perovskite solar cells (PSCs) has led to significant advancement in enhancing the environmental stability of the fabricated devices. ${ }^{17-21}$ The work reported from our group showed that the implementation of ultrathin thermal $\mathrm{ALD} \mathrm{Al}_{2} \mathrm{O}_{3} \quad(<1 \mathrm{~nm})$ directly on top of $\mathrm{CH}_{3} \mathrm{NH}_{3} \mathrm{PbI}_{3-x} \mathrm{Cl}_{x}$ perovskite leads to an enhancement in both initial efficiency and humidity-stability of the PSC in comparison to the $\mathrm{Al}_{2} \mathrm{O}_{3}$-free reference device (humidity conditions ranging from 40 to $70 \%$ at room temperature). ${ }^{22}$

Received: October 19, 2018

Accepted: January 9, 2019

Published: January 9, 2019 
Kot et al. demonstrated the incorporation of room-temperature ALD $\mathrm{Al}_{2} \mathrm{O}_{3}$ on top of both fresh ${ }^{23}$ and 50 days aged $\mathrm{CH}_{3} \mathrm{NH}_{3} \mathrm{PbI}_{3}$ perovskite to improve the power conversion efficiency (PCE) of the PSC and its ambient air stability. The applicability of $\mathrm{ALD} \mathrm{Al}_{2} \mathrm{O}_{3}$ was extended also toward other perovskite chemistries in the work of Loiudice et al., where an ALD $\mathrm{Al}_{2} \mathrm{O}_{3}$ layer was adopted to stabilize $\mathrm{CsPbBr} \mathrm{I}_{3-x}$ and $\mathrm{CsPbI}_{3}$ quantum dots. ${ }^{25}$ In contrast to the above ALD $\mathrm{Al}_{2} \mathrm{O}_{3}$ processes which used trimethylaluminum (TMA) and $\mathrm{H}_{2} \mathrm{O}$ vapor as the precursor and co-reactant respectively, Kim et al. utilized aluminum triisopropoxide and acetic acid in view of a water-free $\mathrm{ALD} \mathrm{Al}_{2} \mathrm{O}_{3}$ process to passivate $\mathrm{CH}_{3} \mathrm{NH}_{3} \mathrm{PbI}_{3}$ perovskite against a relative humidity of $85 \%$, and also to improve the thermal stability of the films up to $250{ }^{\circ} \mathrm{C}$. ${ }^{26}$ Inspired by these seminal studies demonstrating $\mathrm{Al}_{2} \mathrm{O}_{3}$ effects directly on top of perovskites, the application of ALD has expanded further toward other metal oxides, among which $\mathrm{TiO}_{2}, \mathrm{SnO}_{2}$, and $\mathrm{Al}$-doped $\mathrm{ZnO}(\mathrm{AZO})$ were recently shown to act as excellent moisture and thermal stress barrier layers to suppress the degradation of PSCs. ${ }^{27-33}$ However, in most cases, rather than directly on top of the perovskite, the deposition of these metal oxides was performed on $[6,6]$ phenyl-C61 butyric acid methyl ester (PCBM) and other organic charge extraction layers to secure the stability of the underlying sensitive perovskite against the ALD processing conditions.

Aforementioned intriguing results manifest that the growth of ALD metal oxides directly on top of the hybrid perovskites is challenging, and hence, motivate a detailed investigation of the interaction of perovskite with ALD precursors and coreactants during the deposition of metal oxides on top. Understanding the factors governing perovskite chemical modifications and ALD growth behavior would enable the accomplishment of efficient and stable PSCs. In this regard, Choudhury et al. performed in situ Quartz Crystal Microbalance (QCM) and Fourier transform Infrared (IR) spectroscopy measurements on $\mathrm{CH}_{3} \mathrm{NH}_{3} \mathrm{PbI}_{3-\mathrm{x}} \mathrm{Cl}_{x}$ perovskite during its individual interactions with TMA and $\mathrm{H}_{2} \mathrm{O}$ vapor at $75{ }^{\circ} \mathrm{C}$. The results showed that TMA could continuously etch the perovskite at $75{ }^{\circ} \mathrm{C}$, and at the same time could be more detrimental toward perovskite degradation than $\mathrm{H}_{2} \mathrm{O}$ vapor exposure. ${ }^{34}$ Work of $\mathrm{Yu}$ et al. focused on the nucleation of ALD metal oxides on top of the PCBM/perovskite layer. ${ }^{35}$ Kot et al. implemented synchrotron X-ray photoelectron spectroscopy (XPS) to study the room-temperature ALD $\mathrm{Al}_{2} \mathrm{O}_{3} / \mathrm{CH}_{3} \mathrm{NH}_{3} \mathrm{PbI}_{3}$ system, and showed the interaction of ALD precursors to occur only at the surface of the perovskite. $^{36}$ It was demonstrated that chemical changes at the $\mathrm{CH}_{3} \mathrm{NH}_{3} \mathrm{PbI}_{3} / \mathrm{Al}_{2} \mathrm{O}_{3}$ interface could also alter the electronic properties of the perovskite. In situ valence-band XPS results showed changes in the position of the valenceband maximum (VBM) of $\mathrm{CH}_{3} \mathrm{NH}_{3} \mathrm{PbI}_{3}$ with increase in the number of $\mathrm{Al}_{2} \mathrm{O}_{3}$ cycles. ${ }^{23,24}$ In addition, X-ray diffraction (XRD) and XPS were utilized to demonstrate the role of metal-organic precursor chemistry toward maintaining both bulk and surface stability of the perovskite during ALD. ${ }^{17,33,37}$

In this work, we perform in situ IR spectroscopy on $\mathrm{CH}_{3} \mathrm{NH}_{3} \mathrm{PbI}_{3-x} \mathrm{Cl}_{x}$ perovskite to study its structural and chemical modifications during the growth of $\mathrm{ALD} \mathrm{Al}_{2} \mathrm{O}_{3}$ on top, employing TMA as the precursor and $\mathrm{H}_{2} \mathrm{O}$ vapor as the co-reactant at $80{ }^{\circ} \mathrm{C}$. We choose $\mathrm{ALD} \mathrm{Al}_{2} \mathrm{O}_{3}$ for the present study as it is one of the well-established ALD metal oxides, and has already been demonstrated to work successfully in enhancing the stability of PSCs. The in situ IR results are complemented by XPS analysis carried out on the perovskite/ $\mathrm{ALD} \mathrm{Al}_{2} \mathrm{O}_{3}$ interface. Based on the XPS results, we discuss how the growth of $\mathrm{ALD} \mathrm{Al}_{2} \mathrm{O}_{3}$ can initiate and then further develop on top of $\mathrm{CH}_{3} \mathrm{NH}_{3} \mathrm{PbI}_{3-x} \mathrm{Cl}_{x}$ perovskite.

\section{EXPERIMENTAL SECTION}

$\mathrm{CH}_{3} \mathrm{NH}_{3} \mathrm{Pbl}_{3-\mathrm{x}} \mathrm{Cl}_{x}$ Perovskite Film Preparation. The perovskite precursor solution is made by mixing lead acetate $\left(\mathrm{PbAc}_{2}\right)$, lead chloride $\left(\mathrm{PbCl}_{2}\right)$ and methylammonium iodide (MAI) in dimethylformamide (DMF) as previously reported. ${ }^{38} \mathrm{~A} \sim 500 \mu \mathrm{m}$ thick double-side polished Si (100) wafer (n-type doping, 30-50 $\Omega \cdot \mathrm{cm}$ ) with native oxide is used as the substrate. The precursor solution is spin-coated inside a $\mathrm{N}_{2}$ filled glovebox on one side of the double polished Si wafer at $3000 \mathrm{rpm}$ for $60 \mathrm{~s}$. The substrate is subsequently annealed at $130{ }^{\circ} \mathrm{C}$ for $10 \mathrm{~min}$ to form the perovskite layer.

ALD Process of $\mathrm{Al}_{2} \mathrm{O}_{3} \cdot \mathrm{Al}_{2} \mathrm{O}_{3}$ is deposited on top of the perovskite/Si substrate at $80^{\circ} \mathrm{C}$ in a home-built ALD reactor, which is a high-vacuum system that is evacuated by a combination of a rotary and a turbomolecular pump to a base pressure of $\sim 10^{-6}$ mbar. The system has been extensively described in our previous work. ${ }^{39}$ Each ALD cycle consists of a TMA dose of $0.08 \mathrm{~s}$, followed by a purge of $4.0 \mathrm{~s}$, then a $\mathrm{H}_{2} \mathrm{O}$ vapor dose of $0.1 \mathrm{~s}$, followed by a purge of $4.0 \mathrm{~s}$. The thickness of the ALD $\mathrm{Al}_{2} \mathrm{O}_{3}$ layers on the c-Si substrate is characterized by spectroscopic ellipsometry (SE) using J.A. Woollam, Inc. M2000 UV ellipsometer and the growth per cycle (GPC) is determined to be $0.06 \mathrm{~nm}$.

IR Spectroscopy. The IR setup consists of a Bruker Vector 22 Fourier transform IR spectrometer with a mid-infrared light source (Globar $\left.\sim 10000-50 \mathrm{~cm}^{-1}\right)$. The substrate is mounted onto a sample manipulator (PREVAC, four axes manipulator), which enables for a well-controlled movement of the sample in all the $\mathrm{X}, \mathrm{Y}$, and $\mathrm{Z}$ directions. The perovskite/Si substrate is placed vertically with the IR beam, that is, at normal angle of incidence. $\mathrm{KBr}$ windows are used as entry and exit windows for the IR light. In order to prevent deposition on these windows, shutters are installed, and are opened only during the IR measurements. The intensity of the transmitted IR light is measured using a liquid $\mathrm{N}_{2}$ cooled mercury cadmium tellurium (MCT) detector (Bruker D316) in a spectral range of 4000-700 $\mathrm{cm}^{-1}$. The Vector 22 as well as the environment of the MCT detector is continuously purged with dry $\mathrm{N}_{2}$ gas. In addition, before each measurement the reactor is pumped down to a base pressure of $<5 \times$ $10^{-6} \mathrm{mbar}$ in order to minimize contributions from the gas phase species present inside the reactor to the measured transmittance spectra. The perovskite samples are exposed to vacuum conditions of $10^{-6}$ mbar for a maximum of $5 \mathrm{~h}$ during the experiments. All IR measurements performed in this work have been acquired with an average of 1024 scans, and with a resolution of $4 \mathrm{~cm}^{-1}$. The infrared absorbance (A) has been calculated by A $=-\log \left(I_{2} / I_{1}\right)$, where $I_{2}$ and $I_{1}$ are the measured transmittance of the sample after and before $\mathrm{Al}_{2} \mathrm{O}_{3}$ deposition, respectively. The approach adopted for calculating the absorbance on perovskite which is deposited on one side of the double polished Si wafer is schematically presented in Supporting Information (SI) Figure S1 (the absorbance difference between a perovskite/Si substrate and a $\mathrm{Si}$ substrate). It is to be noted that IR spectra measured on pressed pellets are known to sometimes suffer from artifacts, especially when the samples of interest are halide based, due to the possible hydrogen-bond interactions with the pellet materials like $\mathrm{KBr}$ and $\mathrm{KCl}^{40,41}$ Hence, in the present study, we have opted for double-side polished $\mathrm{Si}$ as the substrate.

XRD. XRD analysis is carried out on the perovskite/Si and ALD $\mathrm{Al}_{2} \mathrm{O}_{3}$ /perovskite/Si samples using a PANalytical X'Pert Pro MRD Xray diffractometer using $\mathrm{Cu} K \alpha$ radiation $(\lambda=1.540598 \AA)$ in the $2 \theta$ range $10-60^{\circ}$ at a scanning rate of $1.5^{\circ} \mathrm{min}^{-1}$.

XPS. Ex situ XPS measurements are carried out right after the ALD $\mathrm{Al}_{2} \mathrm{O}_{3}$ deposition on perovskite. The perovskite/ALD $\mathrm{Al}_{2} \mathrm{O}_{3}$ samples are transferred to the XPS setup in $\mathrm{N}_{2}$ filled containers (under dark conditions) and the time of exposure of the samples to ambient air is $<5 \mathrm{~min}$. The measurements are carried out in a Thermo Scientific K- 
Alpha system, equipped with an $\mathrm{Al} \mathrm{X}$-ray source $(\mathrm{K} \alpha, 1486.6 \mathrm{eV})$ without any presputtering. Binding energy is corrected with respect to adventitious carbon $(\mathrm{C} 1 \mathrm{~s})$ at $284.8 \mathrm{eV}$. The peak fit results are obtained using Thermo Avantage software applying Powell fitting algorithm and Gauss-Lorentz Mix. The $\mathrm{Al}_{2} \mathrm{O}_{3}$ film thickness on top of the $\mathrm{Si}$ substrate $\left(d_{\mathrm{Al} 2 \mathrm{O} 3}\right)$ is calculated by measuring the attenuation of the silicon core level using eq 1, which is given as,

$$
I_{\mathrm{S}}=I_{\mathrm{O}} \exp \left[-d_{\mathrm{Al} 2 \mathrm{O} 3} /\left(\lambda_{\mathrm{Al} 2 \mathrm{O} 3} \sin \theta\right)\right]
$$

where, $I_{s}$ is the photoelectron yield with $\mathrm{Al}_{2} \mathrm{O}_{3}$ on $\mathrm{Si}, I_{\mathrm{o}}$ is the photoelectron yield without $\mathrm{Al}_{2} \mathrm{O}_{3}$ on $\mathrm{Si}, d$ is the $\mathrm{Al}_{2} \mathrm{O}_{3}$ thickness $(\mathrm{nm}), \lambda$ is the inelastic mean free path of the electron (nm), and $\theta$ is the XPS takeoff angle (degree). $I_{\mathrm{S}}$ and $I_{\mathrm{o}}$ are obtained by integrating the area under the $\mathrm{Si} 2 \mathrm{p}$ peak $\left(\mathrm{Si}^{0}\right)$, avoiding the $\mathrm{SiO}_{2}\left(\mathrm{Si}^{4+}\right)$ contribution. The inelastic mean free path (IMFP) of electron is obtained from the NIST IMFP database using the TPP-2M formula. ${ }^{42}$ Similar procedure is utilized to calculate the thickness of $\mathrm{ALD} \mathrm{Al}_{2} \mathrm{O}_{3}$ on top of perovskite, by measuring the attenuation of the iodine core level using eq 1 . The photoelectron yields $I_{\mathrm{s}}$ and $I_{\mathrm{o}}$ are obtained by integrating the area under the $\mathrm{I} 3 \mathrm{~d}$ peaks before and after $\mathrm{Al}_{2} \mathrm{O}_{3}$ deposition, respectively. The IMFP of electron is taken to be $2.63 \mathrm{~nm}$ for $\mathrm{Al}_{2} \mathrm{O}_{3}$. The XPS takeoff angle is $90^{\circ}$. It should be noted that the value of $\lambda_{\mathrm{Al} 2 \mathrm{O} 3}$ is dependent on the energy of the employed X-ray photons, binding energy of the element whose attenuation is monitored and also on the density of the overlayer. So, it is recommended to verify the thickness values obtained from XPS by additional characterization techniques such as, $\mathrm{SE}$ and transmission electron microscopy (TEM).

Transmission Electron Microscopy (TEM) and Elemental Mapping. Cross-sectional TEM samples of the stack comprising of perovskite/ALD $\mathrm{Al}_{2} \mathrm{O}_{3} /$ Spiro-OMeTAD are prepared using a standard Focused Ion Beam liftout procedure. In the transfer step, the samples are mounted on molybdenum support grids upon which the final thinning is performed. The TEM studies are performed using a JEOL ARM 200 probe corrected TEM, operated at $200 \mathrm{kV}$, and equipped with a $100 \mathrm{~mm}^{2}$ Centurio SDD energy dispersive X-ray spectroscopy (EDX) detector. EDX mappings of $256 * 256$ full spectra are acquired using a $0.1 \mathrm{~ms}$ dwell time, summing up over 37,128 , and 105 full frame acquisitions. Quantification of the EDX maps is performed using standard $k$-factors.

\section{RESULTS AND DISCUSSION}

Figure 1 shows the IR spectrum of a $\sim 300 \mathrm{~nm}$ thick pristine $\mathrm{CH}_{3} \mathrm{NH}_{3} \mathrm{PbI}_{3-x} \mathrm{Cl}_{x}$ perovskite film. The observed vibrational modes (summarized in Table 1) are in good agreement with those reported in literature. ${ }^{34,41,43-45}$ The most intense vibrational mode is marked by the symmetric and asymmetric $\mathrm{N}-\mathrm{H}$ stretching modes (associated with $\mathrm{NH}_{3}{ }^{+}$) at 3132 and $3179 \mathrm{~cm}^{-1}$, respectively. The absence of $\mathrm{O}-\mathrm{H}$ stretching

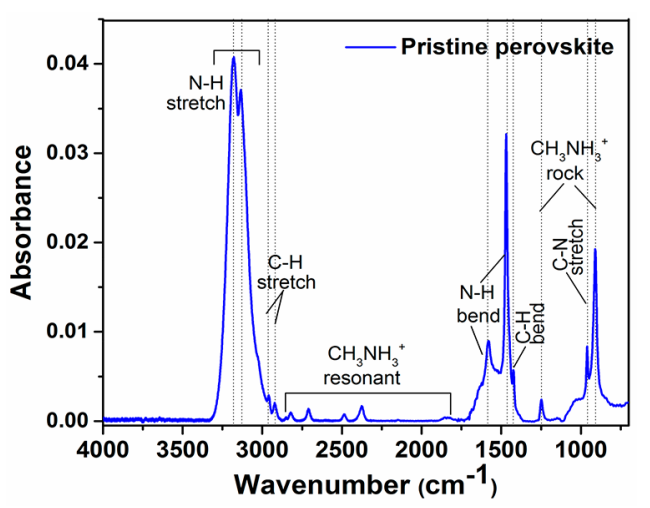

Figure 1. IR spectrum of the pristine $\sim 300 \mathrm{~nm} \mathrm{CH} \mathrm{CH}_{3} \mathrm{NH}_{3} \mathrm{PbI}_{3-x} \mathrm{Cl}_{x}$ perovskite.
Table 1. Characteristic IR-Active Vibrational Modes of the Pristine $\mathrm{CH}_{3} \mathrm{NH}_{3} \mathrm{PbI}_{3-x} \mathrm{Cl}_{x}$ Perovskite

\begin{tabular}{ll}
\multicolumn{1}{c}{ wavenumber $\left(\mathrm{cm}^{-1}\right)$} & \multicolumn{1}{c}{ vibrational mode } \\
3179 & $\mathrm{~N}-\mathrm{H}$ stretch (asymmetric) \\
3132 & $\mathrm{~N}-\mathrm{H}$ stretch (symmetric) \\
2958 & $\mathrm{C}-\mathrm{H}$ stretch (asymmetric) \\
2921 & $\mathrm{C}-\mathrm{H}$ stretch (symmetric) \\
1422 & $\mathrm{C}-\mathrm{H}$ bend \\
1577 & $\mathrm{~N}-\mathrm{H}$ bend (asymmetric) \\
1469 & $\mathrm{~N}-\mathrm{H}$ bend (symmetric) \\
1249,910 & $\mathrm{CH}_{3} \mathrm{NH}_{3}{ }^{+}$rock \\
962 & $\mathrm{C}-\mathrm{N} \mathrm{stretch}_{2817,2711,2488,2375,1840}$ \\
\end{tabular}

vibrations in the region of $3400-3700 \mathrm{~cm}^{-1}$ indicates the absence of hydroxyl species (water, hydrates and hydroxide) in our pristine perovskite films. ${ }^{34,45-47}$

Figure 2 shows the changes which the characteristic IRactive $\mathrm{NH}_{3}{ }^{+}$stretching modes of the perovskite undergoes

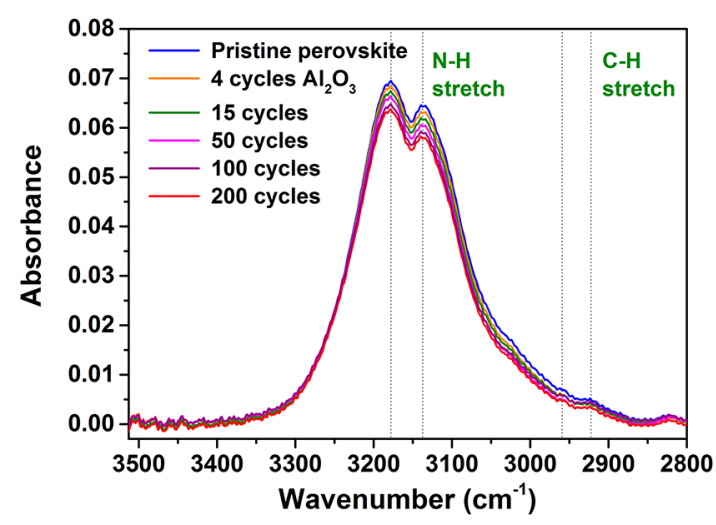

Figure 2. Change in the $\mathrm{N}-\mathrm{H}$ stretching mode of the $\sim 300 \mathrm{~nm}$ thick perovskite upon continuous exposure to cycles of $\mathrm{ALD} \mathrm{Al}_{2} \mathrm{O}_{3}$.

during consecutive cycles of $\mathrm{ALD} \mathrm{Al}_{2} \mathrm{O}_{3}$. A decrease in both symmetric $\left(3132 \mathrm{~cm}^{-1}\right)$ and asymmetric $\left(3179 \mathrm{~cm}^{-1}\right) \mathrm{N}-\mathrm{H}$ stretching modes is evident upon increasing the number of $\mathrm{Al}_{2} \mathrm{O}_{3}$ cycles. At the same time, narrowing of the $\mathrm{NH}_{3}{ }^{+}$stretch band is witnessed, which is accompanied by a minor shift of the symmetric $\mathrm{N}-\mathrm{H}$ stretching mode toward higher frequencies. The observed simultaneous decrease and shift in the symmetric $\mathrm{N}-\mathrm{H}$ stretching vibration can be explained by the interaction of water with the $\mathrm{CH}_{3} \mathrm{NH}_{3}{ }^{+}$group of the perovskite. A similar behavior was observed by Müller et al. when the perovskite was exposed to a relative humidity (R.H.) of $13 \% .{ }^{45}$ However, in contrast to the work of Müller et al., we do not observe the two well-defined peaks at around 3500 and $3450 \mathrm{~cm}^{-1}$ (belonging to asymmetric and symmetric $\mathrm{O}-\mathrm{H}$ stretching modes of $\left.\mathrm{H}_{2} \mathrm{O}\right),{ }^{47}$ indicating that diffusion of water molecules does not occur into the bulk of the perovskite. In the employed $\mathrm{ALD} \mathrm{Al}_{2} \mathrm{O}_{3}$ recipe, the perovskite is exposed to consecutive $\mathrm{H}_{2} \mathrm{O}$ pulses of $1 \times 10^{5} \mathrm{~L}$ which results in a significantly lower R.H. environment (maximum of $0.1 \%$ ) in the ALD chamber. ${ }^{17}$ Hence, the interaction between $\mathrm{H}_{2} \mathrm{O}$ molecule and $\mathrm{CH}_{3} \mathrm{NH}_{3}{ }^{+}$is rather weak during our $\mathrm{H}_{2} \mathrm{O}$ dosage step. This is in agreement with work of $\mathrm{Li}$ et al., where it was shown that $\mathrm{H}_{2} \mathrm{O}$ exposure of below $2 \times 10^{10} \mathrm{~L}$ does cause degradation of $\mathrm{CH}_{3} \mathrm{NH}_{3} \mathrm{PbI}_{3}{ }^{48}$ The IR results indicating negligible bulk decomposition of the perovskite are also 
corroborated by XRD. In Figure 3, the characteristic peaks at $14.11^{\circ}, 28.41^{\circ}$, and $43.21^{\circ}$ can be assigned to the (110), (220),

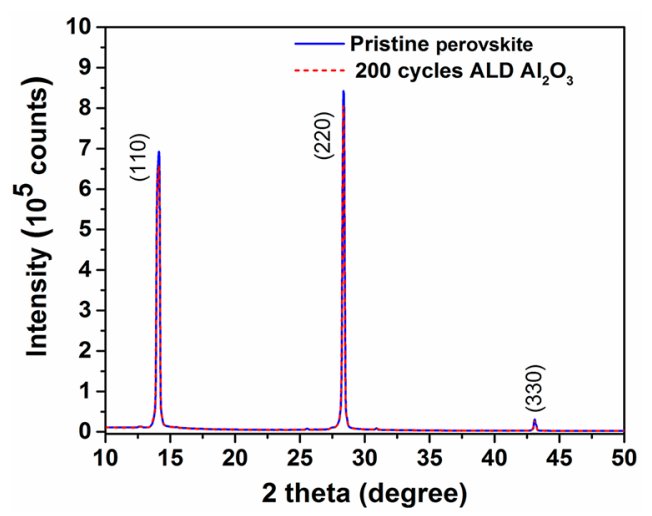

Figure 3. XRD spectra of the perovskite film before and after deposition of 200 cycles of $\mathrm{ALD} \mathrm{Al}_{2} \mathrm{O}_{3}$.

and (330) planes of tetragonal $\mathrm{CH}_{3} \mathrm{NH}_{3} \mathrm{PbI}_{3}$, respectively. The absence of the signature peak at $12.6^{\circ}$ which corresponds to the (001) plane of $\mathrm{PbI}_{2}$, indicates no decomposition of the bulk perovskite even after exposure to 200 cycles of ALD $\mathrm{Al}_{2} \mathrm{O}_{3}$.

From Figures 2 and 3 it can be concluded that the bulk changes which the perovskite material undergoes during the ALD process are negligible. To understand the effect of ALD $\mathrm{Al}_{2} \mathrm{O}_{3}$ on the perovskite surface, the differential IR spectra, which are defined by the difference in absorbance of the perovskite with and without $\mathrm{Al}_{2} \mathrm{O}_{3}$, are analyzed as a function of increasing number of ALD cycles (Figure 4a). In Figure 4a, the $\mathrm{Al}-\mathrm{O}-\mathrm{Al}$ phonon mode in the range of $1000-700 \mathrm{~cm}^{-1}$ and the $(\mathrm{OH})-\mathrm{Al}=\mathrm{O}$ stretching mode at $1080 \mathrm{~cm}^{-1}$ appear already from 15 cycles, and are characteristics of the growth of ALD $\mathrm{Al}_{2} \mathrm{O}_{3}{ }^{49-53}$ It is interesting to note that the shape of the detected $\mathrm{Al}-\mathrm{O}-\mathrm{Al}$ phonon mode on top of perovskite is different as compared to what has been reported earlier for ALD $\mathrm{Al}_{2} \mathrm{O}_{3}$ on top of $\mathrm{Si}^{54-56}$ This might be indicative for a different growth behavior of $\mathrm{ALD} \mathrm{Al}_{2} \mathrm{O}_{3}$ based on the underlying substrate. The peak at $1217 \mathrm{~cm}^{-1}$ pertains to the $\mathrm{Al}-\mathrm{CH}_{3}$ species from unreacted TMA ligands. ${ }^{49,50,57}$ Meanwhile, the presence of negative $\mathrm{N}-\mathrm{H}$ stretching vibrations (3132 and $3179 \mathrm{~cm}^{-1}$ ) indicate abstraction of either $\mathrm{NH}_{3}$ or $\mathrm{CH}_{3} \mathrm{NH}_{2}$ from the perovskite surface. This is corroborated by the complementary decrease in the $\mathrm{N}-\mathrm{H}$ bending vibration at $1468 \mathrm{~cm}^{-1}$. The absence of the asymmetric and symmetric O$\mathrm{H}$ stretching modes of $\mathrm{H}_{2} \mathrm{O}$ at 3500 and $3450 \mathrm{~cm}^{-1}$, respectively, and the minor shift in the symmetric $\mathrm{N}-\mathrm{H}$ stretching vibration with increasing $\mathrm{Al}_{2} \mathrm{O}_{3}$ cycles, again confirms that the interaction of $\mathrm{H}_{2} \mathrm{O}$ molecule with the $\mathrm{CH}_{3} \mathrm{NH}_{3}{ }^{+}$of the perovskite is rather weak in our case. It is to be noted that the vibrational modes pertaining to the $\mathrm{PbI}_{3}$ framework of the perovskite are not IR-active in the range of $4000-500 \mathrm{~cm}^{-1}$ studied in this work. ${ }^{44,58}$ The vibrational modes related to $\mathrm{H}_{2} \mathrm{O}(\mathrm{g})$ and $\mathrm{CO}_{2}(\mathrm{~g})$ originate from the residual gas phase species present in the ALD reactor, as well as from the fluctuations in the $\mathrm{N}_{2}$-purged IR beam path. ${ }^{59}$ The integrated area of the negative $\mathrm{N}-\mathrm{H}$ stretching modes is plotted as a function of ALD cycles in Figure $4 \mathrm{~b}$. As seen, the area decreases exponentially with respect to increasing number of ALD cycles, showing that the effusion of $\mathrm{NH}_{3}$ or $\mathrm{CH}_{3} \mathrm{NH}_{2}$ species occur even after the deposition of 200 cycles of $\mathrm{Al}_{2} \mathrm{O}_{3}$. a)

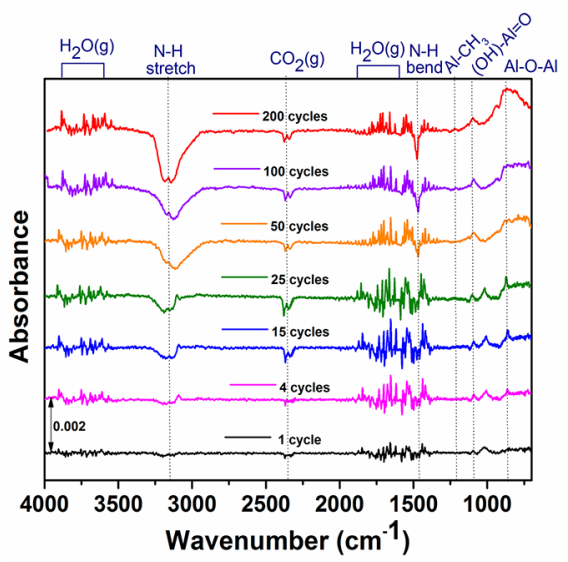

b)

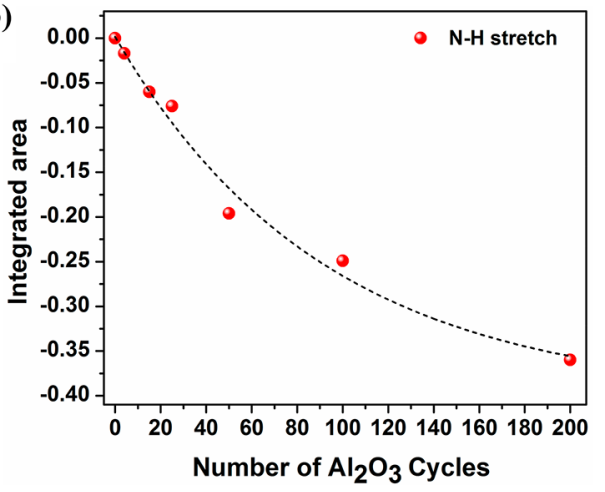

Figure 4. (a) Differential IR spectra (difference in absorbance of the perovskite with and without $\mathrm{Al}_{2} \mathrm{O}_{3}$ ) with increasing number of ALD cycles. (b) Integrated area of the $\mathrm{N}-\mathrm{H}$ stretching mode in (a) as a function of number of $\mathrm{Al}_{2} \mathrm{O}_{3}$ cycles. Absorbance of the $\mathrm{N}-\mathrm{H}$ stretching mode, which is negative compared to the baseline, increases in magnitude with increasing number of ALD cycles. The dashed line is a fit to the exponential function $\exp (-\mathrm{rx})$, where, $x=$ number of $\mathrm{Al}_{2} \mathrm{O}_{3}$ cycles and $r=$ effusion rate of $\mathrm{NH}_{3}$ or $\mathrm{CH}_{3} \mathrm{NH}_{2}$ species per cycle.

It is potentially related to a lower density of the ALD $\mathrm{Al}_{2} \mathrm{O}_{3}$ which is grown at a low deposition temperature of $80{ }^{\circ} \mathrm{C},{ }^{60-62}$ which allows for both out-diffusion of perovskite functional groups and in-diffusion of ALD precursors.

To gain further insight into the chemical modifications in the perovskite surface as observed via IR, XPS analysis is carried out on the perovskite/ALD $\mathrm{Al}_{2} \mathrm{O}_{3}$ interface, for $\mathrm{Al}_{2} \mathrm{O}_{3}$ cycles ranging from 25 to 200 . First, the growth of $\mathrm{Al}_{2} \mathrm{O}_{3}$ is witnessed by the presence of the characteristic $\mathrm{Al} 2 \mathrm{p}$ peak at $74.6 \mathrm{eV}$ as shown in SI Figure S2 for a film obtained with 25 cycles. This corresponds to an $\mathrm{Al}_{2} \mathrm{O}_{3}$ thickness of $<1 \mathrm{~nm}$ on top of perovskite, as was determined by measuring the attenuation of the iodine core level using eq 1 explained in the Experimental Section. Figure 5a presents the $\mathrm{N}$ 1s core level spectra for perovskite before and after deposition of 25 cycles of $\mathrm{Al}_{2} \mathrm{O}_{3}$. The binding energy (B.E.) peak at $402.7 \mathrm{eV}$ which is representative of the $\mathrm{N}-\mathrm{C}$ bonds present in the pristine perovskite decreases and shifts toward lower B.E. values. In addition, a new peak appears at a B.E. of $399.5 \mathrm{eV}$ which is associated to primary or secondary amines. ${ }^{63} \mathrm{~A}$ similar behavior is observed in the $\mathrm{C} 1 \mathrm{~s}$ spectra shown in Figure $5 \mathrm{~b}$ where the disappearance of the characteristic $\mathrm{C}-\mathrm{N}$ B.E. peak at $286.6 \mathrm{eV}$ is well evident after deposition of $25 \mathrm{Al}_{2} \mathrm{O}_{3}$ cycles. At the same time, the intensity of the $\mathrm{C}-\mathrm{C} / \mathrm{C}-\mathrm{H}$ peak at $284.8 \mathrm{eV}$ increases. This can be attributed to the formation of 
a)

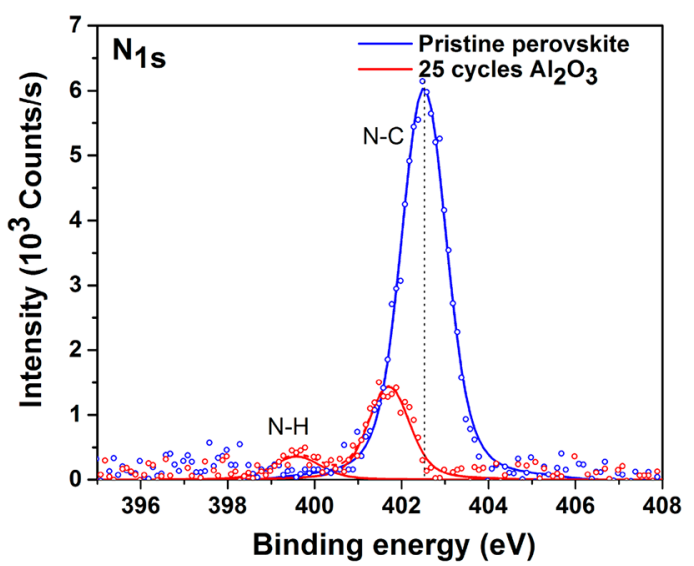

c)

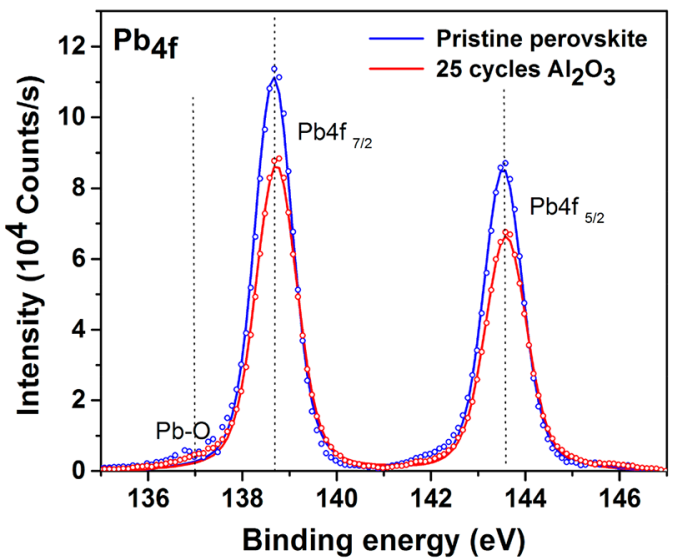

b)

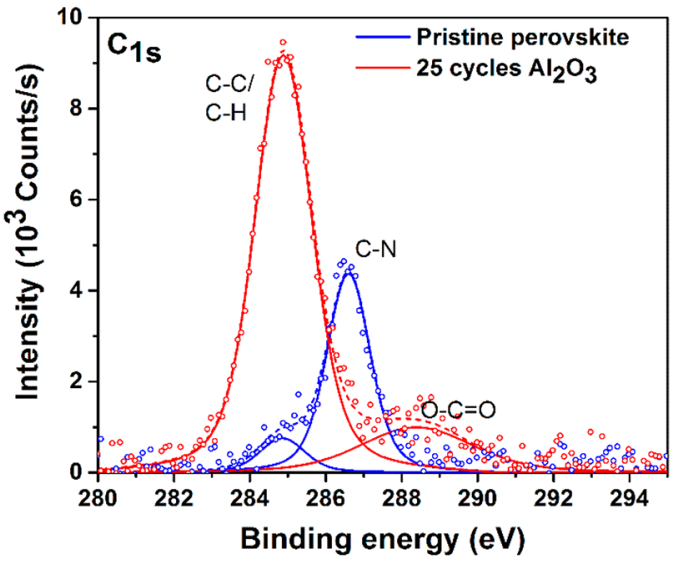

d)

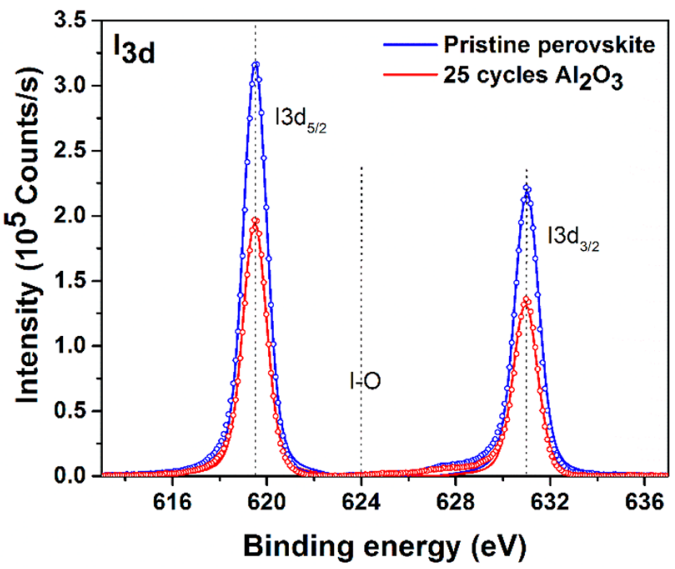

Figure 5. Surface XPS spectra of (a) $\mathrm{N}_{1 s}$, (b) $\mathrm{C}_{1 s}$, (c) $\mathrm{Pb}_{4 \mathrm{f}}$, and (d) $\mathrm{I}_{3 \mathrm{~d}}$ peaks before and after deposition of 25 cycles of $\mathrm{ALD} \mathrm{Al}_{2} \mathrm{O}_{3}$ (corresponding to $<1 \mathrm{~nm}$ ) on top of the perovskite film. Open circles, solid lines and dashed lines are measured data, peak fits, and cumulative fits, respectively.

\section{a)}

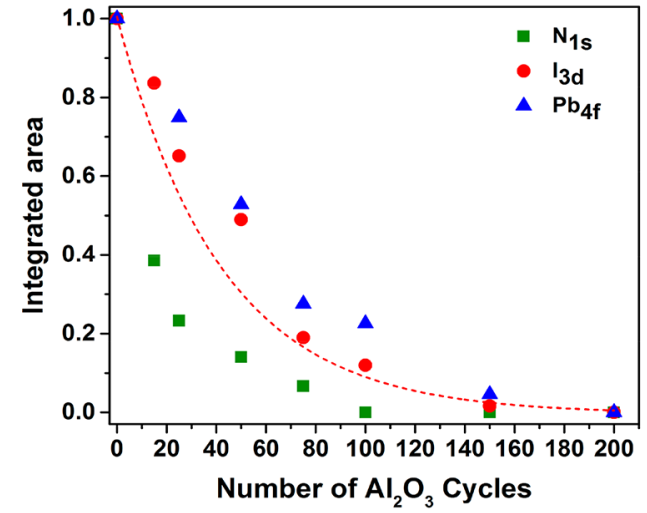

b)

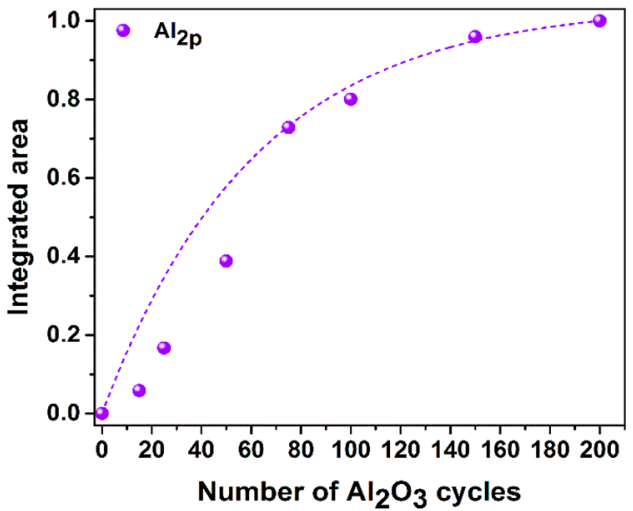

Figure 6. Normalized integrated areas of (a) $\mathrm{N}_{1 \mathrm{~s}}, \mathrm{~Pb}_{4 \mathrm{f}} \mathrm{I}_{3 \mathrm{~d}}$ and (b) $\mathrm{Al}_{2 \mathrm{p}}$ as a function of number of $\mathrm{Al}_{2} \mathrm{O}_{3}$ cycles on perovskite. The dashed lines show predictions assuming a layer-by-layer growth mechanism.

$\mathrm{C}-\mathrm{H}$ bonds due to the deposition of $\mathrm{ALD} \mathrm{Al}_{2} \mathrm{O}_{3}$ on top of the perovskite at a lower temperature of $80{ }^{\circ} \mathrm{C} .{ }^{64}$ At the same time, the $\mathrm{C}-\mathrm{C} / \mathrm{C}-\mathrm{H}$ area is also seen to increase after the deposition of $\mathrm{ALD} \mathrm{Al}_{2} \mathrm{O}_{3}$ on top of $\mathrm{Si}$ substrate (SI Figure S3), confirming that it refers to carbon impurities in the $\mathrm{Al}_{2} \mathrm{O}_{3}$ layer. Meanwhile, monitoring the $\mathrm{Pb} 4 \mathrm{f}$ and $\mathrm{I} 3 \mathrm{~d}$ spectra in Figure $5 \mathrm{c}$ and $\mathrm{d}$, respectively, the formation of $\mathrm{Pb}-\mathrm{O}$ (B.E. 137
$\mathrm{eV}$ ) and $\mathrm{I}-\mathrm{O}$ bonds (B.E. $624 \mathrm{eV}$ ) is not witnessed. This is indicative that the perovskite surface is not oxidized under the employed ALD conditions. In parallel, the reduction of $\mathrm{Pb} 4 \mathrm{f}$ and I $3 \mathrm{~d}$ peak areas is well evident. A discussion on this will be presented later. It is interesting to note that even after 100 cycles of $\mathrm{Al}_{2} \mathrm{O}_{3}$ exposure (corresponding to a thickness of 
a)

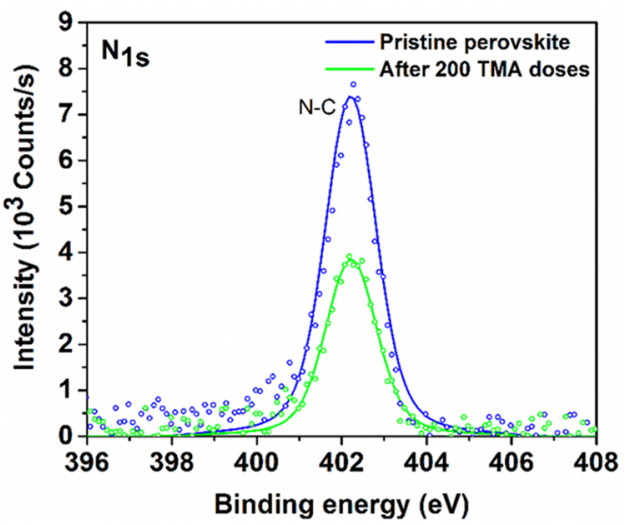

c)

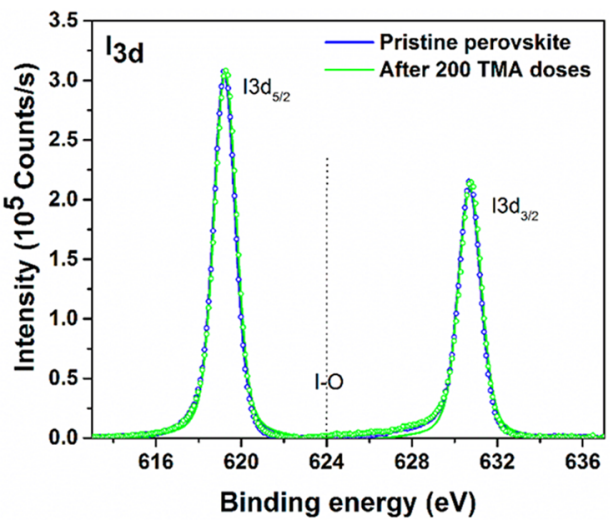

b)

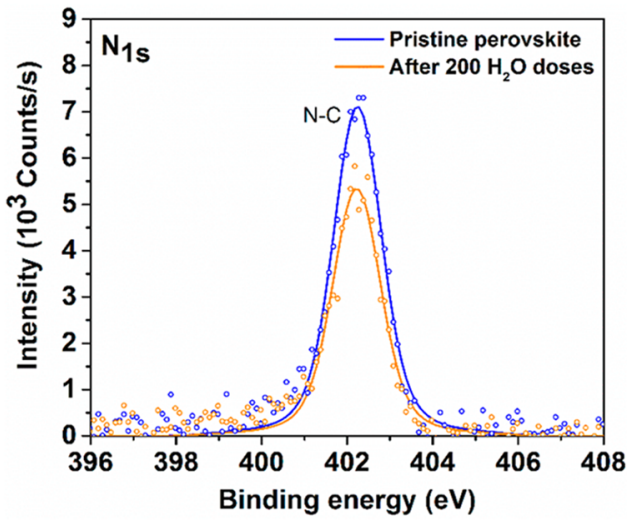

d)

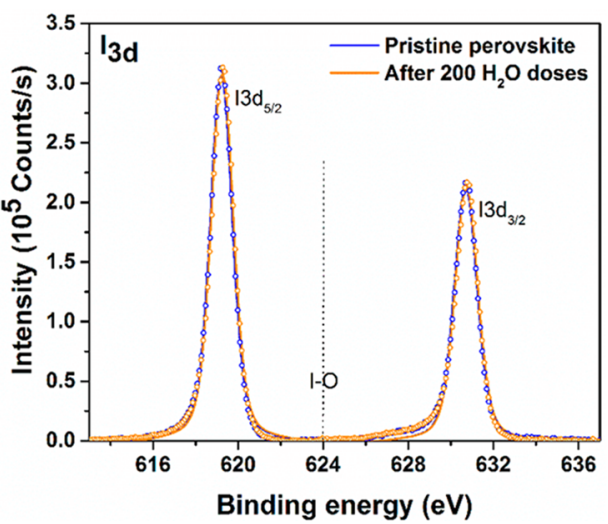

Figure 7. Surface XPS spectra of $\mathrm{N}_{1 \mathrm{~s}}$ and $\mathrm{I}_{3 \mathrm{~d}}$ peaks of the perovskite film before and after (a), (c) $200 \mathrm{TMA}$ doses, and (b), (d) $200 \mathrm{H}_{2} \mathrm{O}$ vapor doses. Open circles and solid lines are measured data and peak fits, respectively.

about $6.7 \mathrm{~nm}$ ), the inorganic framework of the perovskite stays unoxidized, as shown in SI Figure S4.

The intensity of all perovskite elements is generally expected to decrease upon $\mathrm{Al}_{2} \mathrm{O}_{3}$ deposition because of the attenuation length, as predicted by eq 1 . Figure 6 a presents the normalized integrated areas of $\mathrm{Pb} 4 \mathrm{f}, \mathrm{I} 3 \mathrm{~d}$, and $\mathrm{N}$ 1s elements as a function of number of ALD cycles. It is evident that integrated area of $\mathrm{N}$ 1 s decreases significantly faster than the decays of $\mathrm{Pb}$ 4f and I $3 \mathrm{~d}$ areas with increase in the number of $\mathrm{Al}_{2} \mathrm{O}_{3}$ cycles. Therefore, the reduced counts of the $\mathrm{N}-\mathrm{C}$ peak (in Figure $5 \mathrm{a}$ ) and the disappearance of the $\mathrm{C}-\mathrm{N}$ peak (in Figure $5 \mathrm{~b}$ ) point out complete effusion of $\mathrm{CH}_{3} \mathrm{NH}_{2}$ from the perovskite surface. The consumption of the organic moiety as confirmed by XPS, is in agreement with the earlier drawn conclusion of $\mathrm{CH}_{3} \mathrm{NH}_{2}$ abstraction from IR analysis (Figure $4 \mathrm{a}$ ). The dashed line in Figure 6a represents the expected exponential decay of the I $3 \mathrm{~d}$ signal based upon eq 1 . It is interesting to note that the evolution of the integrated areas of $\mathrm{I} 3 \mathrm{~d}$ and $\mathrm{Al} 2 \mathrm{p}$ as a function of number of $\mathrm{Al}_{2} \mathrm{O}_{3}$ cycles on perovskite (Figure 6a,b) is different when compared to the evolution of the integrated areas of $\mathrm{Si} 2 \mathrm{p}$ and $\mathrm{Al} 2 \mathrm{p}$ with increasing $\mathrm{Al}_{2} \mathrm{O}_{3}$ cycles on top of $\mathrm{c}-\mathrm{Si}$ (SI Figure S5). This indicates different growth behavior of ALD $\mathrm{Al}_{2} \mathrm{O}_{3}$ based on the underlying substrate. We speculate that the growth of $\mathrm{ALD} \mathrm{Al}_{2} \mathrm{O}_{3}$ on top of perovskite begins with island formation, followed by a transition to "layer-by-layer" deposition only after 75 ALD cycles. Recently, Kot et al. also demonstrated that the growth of $\mathrm{ALD} \mathrm{Al}_{2} \mathrm{O}_{3}$ initiates in the form of small islands on perovskite. ${ }^{23}$ In addition, similar XPS results were obtained by Baker et al. for "island to layer-bylayer" growth behavior of ALD Pt on W adhesion layers. ${ }^{65}$

In order to discern whether TMA or $\mathrm{H}_{2} \mathrm{O}$ vapor is more deleterious to the perovskite, the drop in the intensities of the $\mathrm{N}-\mathrm{C}$ B.E. peak with respect to individual TMA and $\mathrm{H}_{2} \mathrm{O}$ vapor doses is presented in the $\mathrm{N}$ 1s spectra of Figure $7 \mathrm{a}$ and $7 \mathrm{~b}$, respectively. It is evident that TMA exposure on top of perovskite is more detrimental than $\mathrm{H}_{2} \mathrm{O}$ vapor exposure in our employed $\mathrm{ALD} \mathrm{Al}_{2} \mathrm{O}_{3}$ recipe. Similar conclusions are drawn when analyzing the $\mathrm{C} 1 \mathrm{~s}$ spectra in SI Figure S6. Meanwhile, the I $3 \mathrm{~d}$ counts experience no change irrespective of TMA and $\mathrm{H}_{2} \mathrm{O}$ vapor doses (Figure $7 \mathrm{c}$ and $\mathrm{d}$ ), again confirming the stability of the inorganic framework when exposed to the ALD precursor and co-reactant.

Surface $-\mathrm{OH}$ groups are considered to be the most common/ubiquitous chemisorption sites for TMA on $\mathrm{Si}$ substrates. In SI Figure S7, the absence of the characteristic $\mathrm{OH}$ B.E. peak in the $\mathrm{O} 1 \mathrm{~s}$ spectrum of the pristine perovskite marks the absence of $-\mathrm{OH}$ surface groups in our employed $\mathrm{CH}_{3} \mathrm{NH}_{3} \mathrm{PbI}_{3-x} \mathrm{Cl}_{x}$ perovskite. Therefore, it is interesting to investigate how the growth of $\mathrm{ALD} \mathrm{Al}_{2} \mathrm{O}_{3}$ initiates on top of the employed perovskite. Based on the obtained IR and XPS results, the proposed growth mechanism of $\mathrm{ALD} \mathrm{Al}_{2} \mathrm{O}_{3}$ on top of $\mathrm{CH}_{3} \mathrm{NH}_{3} \mathrm{PbI}_{3-x} \mathrm{Cl}_{x}$ perovskite is schematically represented in Figure 8. During the first half- cycle, TMA reacts with the perovskite surface by interacting with the $\mathrm{CH}_{3} \mathrm{NH}_{3}{ }^{+}$cation. This interaction weakens the hydrogen-bonds between $\mathrm{CH}_{3} \mathrm{NH}_{3}{ }^{+}$and $\mathrm{I}^{-}$of the perovskite, leading to breakdown of 
$-\mathrm{I}_{3} \mathrm{~Pb}-\mathrm{CH}_{3} \mathrm{NH}_{3}^{+}+\underset{\mathrm{CH}_{3}}{\stackrel{\mathrm{Al}_{3}}{\mathrm{CH}_{3}} \mathbf{C H}_{3}} \longrightarrow \mathrm{I} \mathrm{I}_{3} \mathrm{~Pb}-\mathrm{Al}_{3}\left(\mathrm{CH}_{3}\right)_{2}+\mathrm{CH}_{3} \mathrm{NH}_{2}+\mathrm{CH}_{4}$

Figure 8. Proposed reaction mechanism between TMA and perovskite.

the organic moiety from the inorganic framework. This is in accordance with the $\mathrm{N}$ 1s and C 1s XPS results (presented in Figure 7 and SI Figure S6) showing reduced counts of the N$\mathrm{C}$ and $\mathrm{C}-\mathrm{N}$ peaks, respectively upon TMA exposure. Alongside the release of $\mathrm{CH}_{3} \mathrm{NH}_{2}$ and $\mathrm{CH}_{4}$ as byproducts, an adduct comprising of $\mathrm{PbI}_{3}-\mathrm{Al}\left(\mathrm{CH}_{3}\right)_{2}$ is left behind. This $\mathrm{PbI}_{3}-\mathrm{Al}\left(\mathrm{CH}_{3}\right)_{2}$ adduct can then react with the $\mathrm{H}_{2} \mathrm{O}$ molecule during the subsequent half-cycle of $\mathrm{H}_{2} \mathrm{O}$ dosage, and then generate the $-\mathrm{OH}$ surface sites necessary to promote the growth of $\mathrm{Al}_{2} \mathrm{O}_{3}$. The reaction mechanism proposed in this work via experimental investigation is in agreement with the one obtained from density functional theory (DFT) in the work of Choudhury et al. ${ }^{34}$

To study how the growth of $\mathrm{ALD} \mathrm{Al}_{2} \mathrm{O}_{3}$ proceeds on top of perovskite and whether it follows the classical linear behavior which is observed typically on a c-Si substrate, the thicknesses of $\mathrm{Al}_{2} \mathrm{O}_{3}$ deposited on both perovskite and c-Si are calculated from XPS. Recently, Klesko et al. utilized a similar approach with XPS to calculate the thickness of ALD $\mathrm{TiO}_{2}$ grown selectively on top of a $\mathrm{Si}$ substrate. ${ }^{66}$ The thickness of ALD $\mathrm{Al}_{2} \mathrm{O}_{3}$ is first inferred in the case of growth on $\mathrm{c}-\mathrm{Si}$ and is presented in Figure 9a. As expected, the growth behavior of
$\mathrm{Al}_{2} \mathrm{O}_{3}$ is linear with increasing ALD cycles. At the same time, it is well evident from Figure 9a that for all the ALD cycles, the thickness calculated from XPS is in good agreement with the thickness derived from SE, thus, validating the reliability of the XPS method for calculating the thickness of the grown ALD layer. Next, the growth behavior of $\mathrm{ALD} \mathrm{Al}_{2} \mathrm{O}_{3}$ is monitored on top of the perovskite, and the calculated thicknesses from XPS are plotted as a function of the number of ALD cycles in Figure $9 \mathrm{~b}$. It is interesting to see that in case of perovskite, the growth of $\mathrm{ALD} \mathrm{Al}_{2} \mathrm{O}_{3}$ is retarded during the first 75 cycles of deposition (corresponding thickness of about $5 \mathrm{~nm}$ ). Only after 75 cycles, the growth catches up and follows the classical linear behavior. A cross-sectional TEM study is performed on the perovskite/ALD $\mathrm{Al}_{2} \mathrm{O}_{3}$ (200 cycles) interface as shown in Figure $9 \mathrm{c}, \mathrm{d}$. The thickness of $\mathrm{Al}_{2} \mathrm{O}_{3}$ determined from TEM is in agreement with the thickness calculated from XPS.

The reason for the growth delay of $\mathrm{ALD} \mathrm{Al}_{2} \mathrm{O}_{3}$ on top of perovskite is not clear yet and requires further investigation. At present, we hypothesize that $\mathrm{ALD} \mathrm{Al}_{2} \mathrm{O}_{3}$ grows initially in the form of small islands on top of perovskite, and only after 75 cycles $\left(\sim 5 \mathrm{~nm} \mathrm{Al}_{2} \mathrm{O}_{3}\right)$ conformal layer-by-layer growth starts to occur. The formation of a conformal $\mathrm{ALD} \mathrm{Al}_{2} \mathrm{O}_{3}$ layer (after 200 cycles) on top of the perovskite surface is well evident in the EDX elemental mapping acquired using TEM (Figure 9e). Similar behavior was demonstrated recently by Kot et al., where $\mathrm{ALD} \mathrm{Al}_{2} \mathrm{O}_{3}$ was shown to grow initially in the form of small islands on top of perovskite. ${ }^{23}$ At the same time, following the proposed mechanism in this work (Figure 8), a)

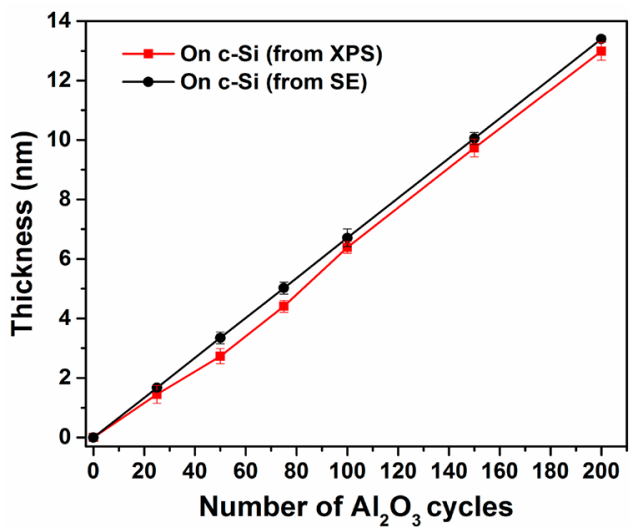

c)

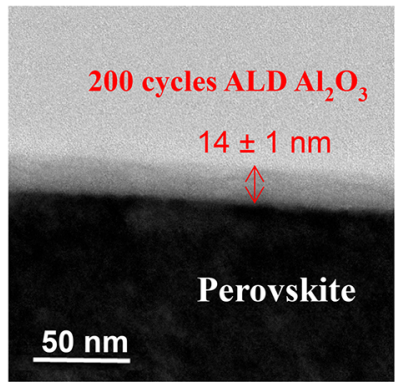

d)

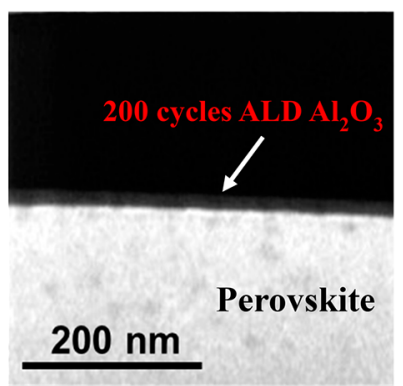

b)

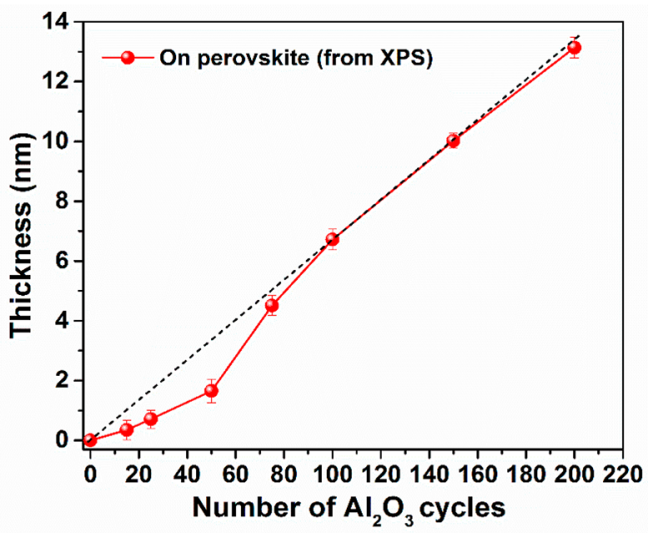

e)

Figure 9. (a) Thickness of $\mathrm{ALD} \mathrm{Al}_{2} \mathrm{O}_{3}$ on top of $\mathrm{Si}$ with increasing number of $\mathrm{ALD}$ cycles derived from XPS and SE (b) Thickness of $\mathrm{ALD} \mathrm{Al}_{2} \mathrm{O}_{3}$ on top of perovskite as a function of number of ALD cycles. The dashed line is a linear fit. The thickness calculation was repeated for three batches to calculate the standard deviation, and thereby the respective error bars. (c), (d) High angle annular dark field (HAADF) scanning TEM crosssectional images of 200 cycles $(14 \pm 1 \mathrm{~nm}) \mathrm{ALD} \mathrm{Al}_{2} \mathrm{O}_{3}$ deposited on top of the perovskite film taken at different resolutions. (e) Corresponding overlapping EDX elemental mapping image. 
one might expect the growth of $\mathrm{Al}_{2} \mathrm{O}_{3}$ on perovskite to accelerate only after exposure to certain number of ALD cycles, possibly, when the organic cation is sufficiently eliminated from the perovskite surface by adequate TMA exposure, which could then lead to the availability of sufficient $-\mathrm{OH}$ surface sites necessary to promote the linear growth behavior of $\mathrm{Al}_{2} \mathrm{O}_{3}$.

\section{CONCLUSIONS}

In summary, the bulk and surface chemical modifications in the $\mathrm{CH}_{3} \mathrm{NH}_{3} \mathrm{PbI}_{3--\mathrm{x}} \mathrm{Cl}_{x}$ perovskite upon growth of $\mathrm{ALD} \mathrm{Al}_{2} \mathrm{O}_{3}$ have been investigated by combining in situ IR spectroscopy study and ex situ XPS analysis. The ALD precursors do not diffuse into the bulk of the perovskite. However, with increasing number of $\mathrm{Al}_{2} \mathrm{O}_{3}$ cycles, abstraction of $\mathrm{NH}_{3}$ or $\mathrm{CH}_{3} \mathrm{NH}_{2}$ from the perovskite surface is witnessed. Meanwhile, XPS analysis confirms the effusion of $\mathrm{CH}_{3} \mathrm{NH}_{2}$ from the perovskite surface, with no oxidation of the inorganic framework. In addition, TMA doses on top of perovskite are found to be more detrimental than $\mathrm{H}_{2} \mathrm{O}$ doses in our employed $\mathrm{ALD} \mathrm{Al}_{2} \mathrm{O}_{3}$ recipe. A plausible growth mechanism of $\mathrm{ALD} \mathrm{Al}_{2} \mathrm{O}_{3}$ on top of perovskite is discussed, where TMA reacts with the perovskite surface by interacting with the $\mathrm{CH}_{3} \mathrm{NH}_{3}{ }^{+}$cation. This reaction releases $\mathrm{CH}_{3} \mathrm{NH}_{2}$ and $\mathrm{CH}_{4}$ as byproducts, and leaves behind an adduct comprising of $\mathrm{PbI}_{3}-$ $\mathrm{Al}\left(\mathrm{CH}_{3}\right)_{2}$ to react with the $\mathrm{H}_{2} \mathrm{O}$ molecule during the subsequent half-cycle of $\mathrm{H}_{2} \mathrm{O}$ dosage, and generate the $-\mathrm{OH}$ surface sites necessary to promote the growth of $\mathrm{Al}_{2} \mathrm{O}_{3}$. An attenuated growth of $\mathrm{Al}_{2} \mathrm{O}_{3}$ is observed on top of perovskite during the first 75 cycles $(\sim 5 \mathrm{~nm})$ of exposure, and, only thereafter, it follows the classical linear behavior that is conventionally seen on top of c-Si substrate. We believe that the insights achieved by in situ IR and XPS studies in this work will contribute to the advancement in engineering of ALD metal oxides directly on perovskite.

\section{ASSOCIATED CONTENT}

\section{S Supporting Information}

The Supporting Information is available free of charge on the ACS Publications website at DOI: 10.1021/acsami.8b18307.

Schematic illustration of the approach followed for calculating the absorbance on perovskite, XPS survey spectra together with additional surface spectra of $\mathrm{Al} 2 \mathrm{p}$, $\mathrm{N} 1 \mathrm{~s}, \mathrm{~Pb} 4 \mathrm{f}$, and I $3 \mathrm{~d}$ peaks before and after deposition of different cycles of $\mathrm{ALD} \mathrm{Al}_{2} \mathrm{O}_{3}$ on top of the perovskite film, $\mathrm{C} 1 \mathrm{~s}$ and $\mathrm{O} 1 \mathrm{~s}$ spectra measured for the perovskite film before and after $200 \mathrm{H}_{2} \mathrm{O}$ vapor doses, $\mathrm{N}$ 1s, C 1s and I $3 \mathrm{~d}$ peaks of the perovskite film before and after 48 $h$ of exposure to vacuum conditions $\left(10^{-9} \mathrm{mbar}\right)$, integrated areas of $\mathrm{Si} 2 \mathrm{p}$ and $\mathrm{Al} 2 \mathrm{p}$ as a function of number of $\mathrm{Al}_{2} \mathrm{O}_{3}$ cycles on top of $\mathrm{c}-\mathrm{Si}$ substrate, change in the $\mathrm{N}-\mathrm{H}$ stretching mode of the perovskite after exposure to $80{ }^{\circ} \mathrm{C}$ for $5 \mathrm{~h}$ inside the ALD chamber (at $10^{-6}$ mbar), change in the $\mathrm{N}-\mathrm{H}$ stretching mode of the perovskite upon continuous exposure to $200 \mathrm{H}_{2} \mathrm{O}$ vapor doses, additional EDX elemental mapping images of elements in the perovskite/ALD $\mathrm{Al}_{2} \mathrm{O}_{3}$ /Spiro-OMeTAD sample (PDF)

\section{AUTHOR INFORMATION}

\section{Corresponding Author}

*E-mail: M.creatore@tue.nl.

\section{ORCID}

Dibyashree Koushik: 0000-0002-7609-3544

Wilhelmus M.M. Kessels: 0000-0002-7630-8226

\section{Notes}

The authors declare no competing financial interest.

\section{ACKNOWLEDGMENTS}

We thank Cristian A. A. van Helvoirt, Caspar O. van Bommel, and Janneke J. A. Zeebregts for the technical support. The authors thank Dr. Alfredo Mameli and Gerben van Straaten for the scientific discussions and Dr. Beatriz Barcones for the focused ion beam (FIB) preparation of the TEM sample. This work is supported by the Light Management in New Photovoltaic Materials (LMPV) research program of The Netherlands Organization for Scientific Research (NWO), and partly by the Dutch Ministry of Economic Affairs, via The Top-consortia Knowledge and Innovation (TKI) Program "High Efficiency Hybrid Tandem Solar Cells" (TEZ0214010). Solliance and the Dutch province of Noord-Brabant are acknowledged for funding the TEM facility.

\section{REFERENCES}

(1) NREL. Best Research-Cell Efficiencies http://www.nrel.gov/ ncpv/images/efficiency_chart.jpg (accessed September 13, 2018).

(2) Ze, W.; Zejiao, S.; Taotao, L.; Yonghua, C.; Wei, H. Stability of Perovskite Solar Cells: A Prospective on the Substitution of the A Cation and X Anion. Angew. Chem., Int. Ed. 2017, 56 (5), 1190-1212.

(3) Wang, D.; Wright, M.; Elumalai, N. K.; Uddin, A. Stability of Perovskite Solar Cells. Sol. Energy Mater. Sol. Cells 2016, 147, 255275.

(4) Niu, G.; Guo, X.; Wang, L. Review of Recent Progress in Chemical Stability of Perovskite Solar Cells. J. Mater. Chem. A 2015, 3 (17), 8970-8980.

(5) Conings, B.; Drijkoningen, J.; Gauquelin, N.; Babayigit, A.; D’Haen, J.; D'Olieslaeger, L.; Ethirajan, A.; Verbeeck, J.; Manca, J.; Mosconi, E.; Angelis, F. D.; Boyen, H.-G. Intrinsic Thermal Instability of Methylammonium Lead Trihalide Perovskite. Adv. Energy Mater. 2015, 5 (15), 1500477.

(6) Fu, X.; Tang, X.; Huang, B.; Hu, T.; Tan, L.; Chen, L.; Chen, Y. Recent Progress on the Long-Term Stability of Perovskite Solar Cells. Adv. Science 2018, 5 (5), 1700387.

(7) Saliba, M.; Matsui, T.; Domanski, K.; Seo, J.-Y.; Ummadisingu, A.; Zakeeruddin, S. M.; Correa-Baena, J.-P.; Tress, W. R.; Abate, A.; Hagfeldt, A.; Grätzel, M. Incorporation of Rubidium Cations into Perovskite Solar Cells Improves Photovoltaic Performance. Science 2016, 354 (6309), 206-209.

(8) Saliba, M.; Matsui, T.; Seo, J.-Y.; Domanski, K.; Correa-Baena, J.-P.; Nazeeruddin, M. K.; Zakeeruddin, S. M.; Tress, W.; Abate, A.; Hagfeldt, A.; Gratzel, M. Cesium-Containing Triple Cation Perovskite Solar Cells: Improved Stability, Reproducibility and High Efficiency. Energy Environ. Sci. 2016, 9 (6), 1989-1997.

(9) Li, Y.; Ji, L.; Liu, R.; Zhang, C.; Mak, C. H.; Zou, X.; Shen, H.H.; Leu, S.-Y.; Hsu, H.-Y. A Review on Morphology Engineering for Highly Efficient and Stable Hybrid Perovskite Solar Cells. J. Mater. Chem. A 2018, 6 (27), 12842-12875.

(10) Bai, Y.; Meng, X.; Yang, S. Interface Engineering for Highly Efficient and Stable Planar p-i-n Perovskite Solar Cells. Adv. Energy Mater. 2018, 8 (5), 1701883.

(11) Lira-Cantú, M. Perovskite Solar Cells: Stability Lies at Interfaces. Nat. Energy 2017, 2, 17115.

(12) Fakharuddin, A.; Schmidt-Mende, L.; Garcia-Belmonte, G.; Jose, R.; Mora-Sero, I. Interfaces in Perovskite Solar Cells. Adv. Energy Mater. 2017, 7 (22), 1700623.

(13) Christians, J. A.; Schulz, P.; Tinkham, J. S.; Schloemer, T. H.; Harvey, S. P.; Tremolet de Villers, B. J.; Sellinger, A.; Berry, J. J.; Luther, J. M. Tailored Interfaces of Unencapsulated Perovskite Solar 
Cells for > 1,000 h Operational Stability. Nat. Energy 2018, 3 (1), 6874.

(14) Hou, Y.; Du, X.; Scheiner, S.; McMeekin, D. P.; Wang, Z.; Li, N.; Killian, M. S.; Chen, H.; Richter, M.; Levchuk, I.; Schrenker, N.; Spiecker, E.; Stubhan, T.; Luechinger, N. A.; Hirsch, A.; Schmuki, P.; Steinrück, H.-P.; Fink, R. H.; Halik, M.; Snaith, H. J.; Brabec, C. J. A Generic Interface to Reduce the Efficiency-Stability-Cost Gap of Perovskite Solar Cells. Science 2017, 358 (6367), 1192-1197.

(15) Rajagopal, A.; Yao, K.; Jen, A. K.-Y. Toward Perovskite Solar Cell Commercialization: A Perspective and Research Roadmap Based on Interfacial Engineering. Adv. Mater. 2018, 30, 1800455.

(16) Pérez-del-Rey, D.; Boix, P. P.; Sessolo, M.; Hadipour, A.; Bolink, H. J. Interfacial Modification for High-Efficiency Vapor-PhaseDeposited Perovskite Solar Cells Based on a Metal Oxide Buffer Layer. J. Phys. Chem. Lett. 2018, 9 (5), 1041-1046.

(17) Zardetto, V.; Williams, B. L.; Perrotta, A.; Di Giacomo, F.; Verheijen, M. A.; Andriessen, R.; Kessels, W. M. M.; Creatore, M. Atomic Layer Deposition for Perovskite Solar Cells: Research Status, Opportunities and Challenges. Sustain. Energy Fuels 2017, 1 (1), 3055.

(18) Deng, K.; Li, L. Advances in the Application of Atomic Layer Deposition for Organometal Halide Perovskite Solar Cells. Adv. Mater. Interfaces 2016, 3 (21), 1600505.

(19) Choi, E. Y.; Kim, J.; Lim, S.; Han, E.; Ho-Baillie, A. W. Y.; Park, N. Enhancing Stability for Organic-Inorganic Perovskite Solar Cells by Atomic Layer Deposited $\mathrm{Al}_{2} \mathrm{O}_{3}$ Encapsulation. Sol. Energy Mater. Sol. Cells 2018, 188, 37-45.

(20) Ramos, F. J.; Maindron, T.; Béchu, S.; Rebai, A.; Frégnaux, M.; Bouttemy, M.; Rousset, J.; Schulz, P.; Schneider, N. Versatile Perovskite Solar Cell Encapsulation by Low-Temperature ALD$\mathrm{Al}_{2} \mathrm{O}_{3}$ with Long-Term Stability Improvement. Sustain. Energy Fuels 2018, 2, 2468-2479.

(21) Dong, X.; Fang, X.; Lv, M.; Lin, B.; Zhang, S.; Ding, J.; Yuan, $\mathrm{N}$. Improvement of the Humidity Stability of Organic-Inorganic Perovskite Solar Cells Using Ultrathin $\mathrm{Al}_{2} \mathrm{O}_{3}$ Layers Prepared by Atomic Layer Deposition. J. Mater. Chem. A 2015, 3 (10), 53605367.

(22) Koushik, D.; Verhees, W. J. H.; Kuang, Y.; Veenstra, S.; Zhang, D.; Verheijen, M. A.; Creatore, M.; Schropp, R. E. I. High-Efficiency Humidity-Stable Planar Perovskite Solar Cells Based on Atomic Layer Architecture. Energy Environ. Sci. 2017, 10 (1), 91-100.

(23) Kot, M.; Kegelmann, L.; Das, C.; Kus, P.; Tsud, N.; Matolinova, I.; Albrecht, S.; Matolin, V.; Schmeisser, D. Room Temperature Atomic Layer Deposited $\mathrm{Al}_{2} \mathrm{O}_{3}$ Improves Perovskite Solar Cells Efficiency Over Time. ChemSusChem 2018, 11, 3640.

(24) Kot, M.; Das, C.; Wang, Z.; Henkel, K.; Rouissi, Z.; Wojciechowski, K.; Snaith, H. J.; Schmeisser, D. Room-Temperature Atomic Layer Deposition of $\mathrm{Al}_{2} \mathrm{O}_{3}$ : Impact on Efficiency, Stability and Surface Properties in Perovskite Solar Cells. ChemSusChem 2016, 9 (24), 3401-3406.

(25) Loiudice, A.; Saris, S.; Oveisi, E.; Alexander, D. T. L.; Buonsanti, R. CsPbBr3 QD/AlOx Inorganic Nanocomposites with Exceptional Stability in Water, Light, and Heat. Angew. Chem., Int. Ed. 2017, 56 (36), 10696-10701.

(26) Kim, I. S.; Martinson, A. B. F. Stabilizing Hybrid Perovskites Against Moisture and Temperature via Non-Hydrolytic Atomic Layer Deposited Overlayers. J. Mater. Chem. A 2015, 3 (40), 20092-20096.

(27) Brinkmann, K. O.; Zhao, J.; Pourdavoud, N.; Becker, T.; Hu, T.; Olthof, S.; Meerholz, K.; Hoffmann, L.; Gahlmann, T.; Heiderhoff, R.; Oszajca, M. F.; Luechinger, N. A.; Rogalla, D.; Chen, Y.; Cheng, B.; Riedl, T. Suppressed Decomposition of Organometal Halide Perovskites by Impermeable Electron-Extraction Layers in Inverted Solar Cells. Nat. Commun. 2017, 8, 13938.

(28) Zhao, J.; Brinkmann, K. O.; Hu, T.; Pourdavoud, N.; Becker, T.; Gahlmann, T.; Heiderhoff, R.; Polywka, A.; Görrn, P.; Chen, Y.; Cheng, B.; Riedl, T. Self-Encapsulating Thermostable and AirResilient Semitransparent Perovskite Solar Cells. Adv. Energy Mater. 2017, 7 (14), 1602599.
(29) Kim, I. S.; Cao, D. H.; Buchholz, D. B.; Emery, J. D.; Farha, O. K.; Hupp, J. T.; Kanatzidis, M. G.; Martinson, A. B. F. Liquid Waterand Heat-Resistant Hybrid Perovskite Photovoltaics via An Inverted ALD Oxide Electron Extraction Layer Design. Nano Lett. 2016, 16 (12), 7786-7790.

(30) Bush, K. A.; Palmstrom, A. F.; Yu, Z. J.; Boccard, M.; Cheacharoen, R.; Mailoa, J. P.; McMeekin, D. P.; Hoye, R. L. Z.; Bailie, C. D.; Leijtens, T.; Peters, I. M.; Minichetti, M. C.; Rolston, N.; Prasanna, R.; Sofia, S.; Harwood, D.; Ma, W.; Moghadam, F.; Snaith, H. J.; Buonassisi, T.; Holman, Z. C.; Bent, S. F.; McGehee, M. D. 23.6\%-Efficient Monolithic Perovskite/Silicon Tandem Solar Cells with Improved Stability. Nat. Energy 2017, 2, 17009.

(31) Seo, S.; Jeong, S.; Bae, C.; Park, N.-G.; Shin, H. Perovskite Solar Cells with Inorganic Electron- and Hole-Transport Layers Exhibiting Long-Term $(\approx 500 \mathrm{~h})$ Stability at $85{ }^{\circ} \mathrm{C}$ under Continuous 1 Sun Illumination in Ambient Air. Adv. Mater. 2018, 30, 1801010.

(32) Hu, X.; Jiang, X.-F.; Xing, X.; Nian, L.; Liu, X.; Huang, R.; Wang, K.; Yip, H.-L.; Zhou, G. Wide-Bandgap Perovskite Solar Cells With Large Open-Circuit Voltage of $1653 \mathrm{mV}$ Through Interfacial Engineering. Sol. RRL 2018, 2, 1800083.

(33) Palmstrom, A. F.; Raiford, J. A.; Prasanna, R.; Bush, K. A.; Sponseller, M.; Cheacharoen, R.; Minichetti, M. C.; Bergsman, D. S.; Leijtens, T.; Wang, H.-P.; Bulović, V.; McGehee, M. D.; Bent, S. F. Interfacial Effects of Tin Oxide Atomic Layer Deposition in Metal Halide Perovskite Photovoltaics. Adv. Energy Mater. 2018, 8, 1800591.

(34) Choudhury, D.; Rajaraman, G.; Sarkar, S. K. Self Limiting Atomic Layer Deposition of $\mathrm{Al}_{2} \mathrm{O}_{3}$ on Perovskite Surfaces: A Reality? Nanoscale 2016, 8 (14), 7459-7465.

(35) Yu, X.; Yan, H.; Peng, Q. Improve the Stability of Hybrid Halide Perovskite via Atomic Layer Deposition on Activated PhenylC61 Butyric Acid Methyl Ester. ACS Appl. Mater. Interfaces 2018, 10 (34), 28948-28954.

(36) Kot, M.; Das, C.; Henkel, K.; Wojciechowski, K.; Snaith, H. J.; Schmeisser, D. Room Temperature Atomic Layer Deposited $\mathrm{Al}_{2} \mathrm{O}_{3}$ on $\mathrm{CH}_{3} \mathrm{NH}_{3} \mathrm{PbI}_{3}$ Characterized by Synchrotron-Based X-ray Photoelectron Spectroscopy. Nucl. Instrum. Methods Phys. Res., Sect. B 2017, 411, 49-52.

(37) Hultqvist, A.; Aitola, K.; Sveinbjörnsson, K.; Saki, Z.; Larsson, F.; Törndahl, T.; Johansson, E.; Boschloo, G.; Edoff, M. Atomic Layer Deposition of Electron Selective $\mathrm{SnOx}$ and $\mathrm{ZnO}$ Films on Mixed Halide Perovskite: Compatibility and Performance. ACS Appl. Mater. Interfaces 2017, 9 (35), 29707-29716.

(38) Qiu, W.; Merckx, T.; Jaysankar, M.; Masse de la Huerta, C.; Rakocevic, L.; Zhang, W.; Paetzold, U. W.; Gehlhaar, R.; Froyen, L.; Poortmans, J.; Cheyns, D.; Snaith, H. J.; Heremans, P. Pinhole-Free Perovskite Films for Efficient Solar Modules. Energy Environ. Sci. 2016, 9 (2), 484-489.

(39) Heil, S. B. S.; Langereis, E.; Roozeboom, F.; van de Sanden, M. C. M.; Kessels, W. M. M. Low-Temperature Deposition of TiN by Plasma-Assisted Atomic Layer Deposition. J. Electrochem. Soc. 2006, 153 (11), G956-G965.

(40) Bellanato, J. Infra-Red Spectra of Ethylenediamine Dihydrochloride and Other Amine Hydrochlorides in Alkali Halide Disks. Spectrochim. Acta 1960, 16 (11), 1344-1357.

(41) Glaser, T.; Müller, C.; Sendner, M.; Krekeler, C.; Semonin, O. E.; Hull, T. D.; Yaffe, O.; Owen, J. S.; Kowalsky, W.; Pucci, A.; Lovrinčić, R. Infrared Spectroscopic Study of Vibrational Modes in Methylammonium Lead Halide Perovskites. J. Phys. Chem. Lett. 2015, 6 (15), 2913-2918.

(42) Tanuma, S.; Powell, C. J.; Penn, D. R. Calculations of Electron Inelastic Mean Free Paths. III. Data for 15 Inorganic Compounds over the 50-2000 eV Range. Surf. Interface Anal. 2003, 35, 268.

(43) Yu, X.; Qin, Y.; Peng, Q. Probe Decomposition of Methylammonium Lead Iodide Perovskite in $\mathrm{N} 2$ and $\mathrm{O} 2$ by in Situ Infrared Spectroscopy. J. Phys. Chem. A 2017, 121 (6), 1169-1174.

(44) Pérez-Osorio, M. A.; Milot, R. L.; Filip, M. R.; Patel, J. B.; Herz, L. M.; Johnston, M. B.; Giustino, F. Vibrational Properties of the Organic-Inorganic Halide Perovskite $\mathrm{CH} 3 \mathrm{NH} 3 \mathrm{PbI} 3$ from Theory and Experiment: Factor Group Analysis, First-Principles Calculations, 
and Low-Temperature Infrared Spectra. J. Phys. Chem. C 2015, 119 (46), 25703-25718.

(45) Müller, C.; Glaser, T.; Plogmeyer, M.; Sendner, M.; Döring, S.; Bakulin, A. A.; Brzuska, C.; Scheer, R.; Pshenichnikov, M. S.; Kowalsky, W.; Pucci, A.; Lovrinčić, R. Water Infiltration in Methylammonium Lead Iodide Perovskite: Fast and Inconspicuous. Chem. Mater. 2015, 27 (22), 7835-7841.

(46) Halder, A.; Choudhury, D.; Ghosh, S.; Subbiah, A. S.; Sarkar, S. K. Exploring Thermochromic Behavior of Hydrated Hybrid Perovskites in Solar Cells. J. Phys. Chem. Lett. 2015, 6 (16), 3180-3184.

(47) Zhu, Z.; Hadjiev, V. G.; Rong, Y.; Guo, R.; Cao, B.; Tang, Z.; Qin, F.; Li, Y.; Wang, Y.; Hao, F.; Venkatesan, S.; Li, W.; Baldelli, S.; Guloy, A. M.; Fang, H.; Hu, Y.; Yao, Y.; Wang, Z.; Bao, J. Interaction of Organic Cation with Water Molecule in Perovskite MAPbI3: From Dynamic Orientational Disorder to Hydrogen Bonding. Chem. Mater. 2016, 28 (20), 7385-7393.

(48) Li, Y.; Xu, X.; Wang, C.; Wang, C.; Xie, F.; Yang, J.; Gao, Y. Degradation by Exposure of Coevaporated $\mathrm{CH} 3 \mathrm{NH} 3 \mathrm{PbI} 3$ Thin Films. J. Phys. Chem. C 2015, 119 (42), 23996-24002.

(49) Frank, M. M.; Chabal, Y. J.; Green, M. L.; Delabie, A.; Brijs, B.; Wilk, G. D.; Ho, M.-Y.; Rosa, E. B. O. d.; Baumvol, I. J. R.; Stedile, F. C. Enhanced Initial Growth of Atomic-Layer-Deposited Metal Oxides on Hydrogen-Terminated Silicon. Appl. Phys. Lett. 2003, 83 (4), $740-742$.

(50) Frank, M. M.; Chabal, Y. J.; Wilk, G. D. Nucleation and Interface Formation Mechanisms in Atomic Layer Deposition of Gate Oxides. Appl. Phys. Lett. 2003, 82 (26), 4758-4760.

(51) Fan, G.; Wang, Y.; Wang, C. One-Pot Synthesis of Aluminum Oxyhydroxide Matrix-Entrapped Pt Nanoparticles as an Excellent Catalyst for the Hydrogenation of Nitrobenzene. RSC Adv. 2014, 4 (21), 10997-11002.

(52) Shen, S. C.; Chen, Q.; Chow, P. S.; Tan, G. H.; Zeng, X. T.; Wang, Z.; Tan, R. B. H. Steam-Assisted Solid Wet-Gel Synthesis of High-Quality Nanorods of Boehmite and Alumina. J. Phys. Chem. C 2007, 111 (2), 700-707.

(53) Vazhayal, L.; Kumar Sasidharan, N.; Talasila, S.; Kumar, D. B. S.; Solaiappan, A. Supramolecular Association of 2D AluminoSiloxane Aquagel Building Blocks to 3D Porous Cages and its Efficacy for Topical and Injectable Delivery of Fluconazole, An Antifungal Drug. J. Mater. Chem. B 2015, 3 (29), 5978-5990.

(54) Levrau, E.; Van de Kerckhove, K.; Devloo-Casier, K.; Pulinthanathu Sree, S.; Martens, J. A.; Detavernier, C.; Dendooven, J. In Situ IR Spectroscopic Investigation of Alumina ALD on Porous Silica Films: Thermal versus Plasma-Enhanced ALD. J. Phys. Chem. C 2014, 118 (51), 29854-29859.

(55) Bartram, M. E.; Michalske, T. A.; Rogers, J. W. A Reexamination of the Chemisorption of Trimethylaluminum on Silica. J. Phys. Chem. 1991, 95 (11), 4453-4463.

(56) Dillon, A. C.; Ott, A. W.; Way, J. D.; George, S. M. Surface Chemistry of $\mathrm{Al}_{2} \mathrm{O}_{3}$ Deposition Using $\mathrm{Al}(\mathrm{CH} 3) 3$ and $\mathrm{H} 2 \mathrm{O}$ in a Binary Reaction Sequence. Surf. Sci. 1995, 322 (1), 230-242.

(57) Goldstein, D. N.; McCormick, J. A.; George, S. M. Al2O3 Atomic Layer Deposition with Trimethylaluminum and Ozone Studied by in Situ Transmission FTIR Spectroscopy and Quadrupole Mass Spectrometry. J. Phys. Chem. C 2008, 112 (49), 19530-19539. (58) Idigoras, J.; Todinova, A.; Sanchez-Valencia, J. R.; Barranco, A.; Borras, A.; Anta, J. A. The Interaction Between Hybrid OrganicInorganic Halide Perovskite and Selective Contacts in Perovskite Solar Cells: An Infrared Spectroscopy Study. Phys. Chem. Chem. Phys. 2016, 18 (19), 13583-13590.

(59) Bosch, R. H. E. C.; Cornelissen, L. E.; Knoops, H. C. M.; Kessels, W. M. M. Atomic Layer Deposition of Silicon Nitride from Bis(tertiary-butyl-amino)silane and N2 Plasma Studied by in Situ Gas Phase and Surface Infrared Spectroscopy. Chem. Mater. 2016, 28 (16), 5864-5871.

(60) Dingemans, G.; Kessels, W. M. M. Status and Prospects of Al2O3-Based Surface Passivation Schemes for Silicon Solar Cells. J. Vac. Sci. Technol., A 2012, 30 (4), 040802.
(61) Groner, M. D.; Fabreguette, F. H.; Elam, J. W.; George, S. M. Low-Temperature Al2O3 Atomic Layer Deposition. Chem. Mater. 2004, 16 (4), 639-645.

(62) Potts, S. E.; Keuning, W.; Langereis, E.; Dingemans, G.; van de Sanden, M. C. M.; Kessels, W. M. M. Low Temperature PlasmaEnhanced Atomic Layer Deposition of Metal Oxide Thin Films. J. Electrochem. Soc. 2010, 157 (7), P66-P74.

(63) Yun, J. H.; Lee, I.; Kim, T.-S.; Ko, M. J.; Kim, J. Y.; Son, H. J. Synergistic Enhancement and Mechanism Study of Mechanical and Moisture Stability of Perovskite Solar Cells Introducing PolyethyleneImine into the $\mathrm{CH} 3 \mathrm{NH} 3 \mathrm{PbI} 3 / \mathrm{HTM}$ Interface. J. Mater. Chem. A 2015, 3 (44), 22176-22182.

(64) Vandalon, V.; Kessels, W. M. M. What is Limiting LowTemperature Atomic Layer Deposition of Al2O3? A Vibrational SumFrequency Generation Study. Appl. Phys. Lett. 2016, 108 (1), 011607.

(65) Baker, L.; Cavanagh, A. S.; Yin, J.; George, S. M.; Kongkanand, A.; Wagner, F. T. Growth of Continuous and Ultrathin Platinum Films on Tungsten Adhesion Layers Using Atomic Layer Deposition Techniques. Appl. Phys. Lett. 2012, 101 (11), 111601.

(66) Klesko, J. P.; Rahman, R.; Dangerfield, A.; Nanayakkara, C. E.; L’Esperance, T.; Moser, D. F.; Peña, L. F.; Mattson, E. C.; Dezelah, C. L.; Kanjolia, R. K.; Chabal, Y. J. Selective Atomic Layer Deposition Mechanism for Titanium Dioxide Films with (EtCp)Ti(NMe2)3: Ozone versus Water. Chem. Mater. 2018, 30 (3), 970-981. 